\title{
Biopsychosocial Impact of Breast Cancer Patients: A Literature Review
}

\author{
Kartika Wijayanti ${ }^{1}$, Suryo Ediyono ${ }^{2}$ \\ \{kartikawijayanti@ummgl.ac.id $\left.{ }^{1}\right\}$ \\ Maternity Nursing of Department, Universitas Muhammadiyah Magelang, 56172, Indonesia ${ }^{1}$
Cultural Science of Department, Universitas Sebelas Maret, 57126, Indonesia ${ }^{2}$
}

\begin{abstract}
The purpose of this literature review is to see the biopsychosocial impact of breast cancer sufferers in Indonesia. The literature review method uses secondary data from previous research on the biopsychosocial impact of breasts cancer in Indonesia, which was searched using the Google Scholar search engine and Pubmed from 2015 to 2020. The results of the literature review stated that 20 journals show the biological/physical impact felt by sufferers' cancer is pain, nausea, vomiting, weight loss, hair loss, skin discoloration, and decreased appetite. The psychological impact that is felt is fear of death, anxiety, shame, depression, even to the level of suicidal thoughts. The impacts that occur in breast cancer sufferers are in the form of biological/physical impacts, psychological impacts and social impacts that require intervention to overcome them. Suggestion: it is necessary to do non-pharmaceutical therapy to deal with client complaints so that it can support the patient's current medical therapy.
\end{abstract}

Keywords: Breast cancer, physiology impact, psychology impact, social impact

\section{Introduction}

Breast cancer is one of the most common types of cancer in women, although there are some men who suffer from breast cancer. The incidence of breast cancer in men in America is less than $1 \%$. Meanwhile, the incidence of women is mostly in the 70-year age group and the least is the 20-year age group [1]. The incidence of breast cancer increases with age. The incidence of breast cancer increases with the times with various causes of changes in people's lifestyles such as alcoholic drinks, rarely exercise, smoking habits, and high-fat foods which are one of the risk factors for triggering the incidence of breast cancer [2]. Other studies suggest that genetics, menopause, hormonal contraceptives are also determinant factors for breast cancer [3]. The incidence of cancer in Central Java ranks first in Indonesia with breast cancer being one of the most common types of cancer [4].

Some of the effects of breast cancer include negative behavior in social relationships, physiological disabilities, shaky belief/spirituality, psychological instability, and decreased enthusiasm for life. Another study states that patients also want to commit suicide because they feel fear, anxiety, sadness, shame, anger at God, loss of selfconfidence, stress, depression and hopelessness. In addition, the environment also affects sufferers, because an uncomfortable environment will increase stress. The main support comes from the closest people to increase the enthusiasm for life and motivation of the sufferer. Economic problems also have an effect, especially financially, for routine medical expenses, adding to the burden on sufferers [5]. Other 
studies have also stated that breast cancer sufferers also experience body image disorders [6]. Several measures to carry out screening have been programmed by the government, including breast self-examination (BSE), clinical breast examination (SADARNIS), and screening mammography (K8). Nursing management for breast cancer consists of interventions, programs, and screening. Interventions for breast cancer include: reducing fatigue, pain, anxiety, menoupouse symptoms, overcoming nausea, improving quality of life, and physical activity). Some programs for breast cancer patients include nutritional fulfillment, physical activities to reduce mucositis and lymphadema, as well as programs to increase knowledge, treatment techniques and increase discomfort. While the screening activity consists of several activities to explore problems experienced by clients with breast cancer [7].

The Ministry of Health stated that the breast cancer rate in Indonesia has reached 42.1 people per 100,000 population. The average death rate from this cancer reaches 17 people per 100,000 population. Global Cancer Observatory 2018 data from the World Health Organization (WHO) shows that the most cancer cases in Indonesia are breast cancer, which is 58,256 cases or $16.7 \%$ of the total 348,809 cancer cases. Cervical cancer (cervix) is the second most common type of cancer in Indonesia with 32,469 cases or $9.3 \%$ of total cases. Efforts to prevent and control both types of cancer are carried out by early detection in women aged 30-50 years. The factor that greatly influences the incidence of breast cancer is a family history of breast cancer (To optimize cancer prevention and control efforts in Indonesia, it is necessary to have massive efforts made by all parties, both government and society. The importance of public awareness for early detection. The earlier the disease is discovered, and received early treatment, the chances of recovery are much greater. Breast cancer is a type of malignant tumor that develops in breast cells. This cancer can grow if there is an abnormal growth of cells in the breast. These cells divide faster than normal cells and accumulate, which then forms a lump or mass. In a more severe stage, these abnormal cells can spread through the lymph nodes to other organs. Sentenced to have breast cancer would certainly be the most heartbreaking news for a woman.

Naturally, women with breast cancer experience a range of emotions, ranging from anger, despair, to depression. Especially after undergoing breast removal surgery, the risk of a person developing serious mental health problems can also occur. Breast cancer is the most common cancer in women and is the most worrying cause of death. Not only can it cause painful physical symptoms, even lifethreatening, breast cancer also often causes psychological effects that reduce the spirit of the sufferer. Besides these two effects, breast cancer also has an impact on social relations. Examples of physical effects on breast cancer are hair loss, pain, loss of appetite, sour or bitter taste in the mouth, nausea and vomiting, shortness of breath and heart rate abnormalities due to anemia, dry and sore skin, bleeding such as easy bruising, bleeding gums, and nosebleeds, frequent infections, difficulty sleeping, feeling tired and weak throughout the day, decreased sexual desire and impaired fertility (infertility), constipation or diarrhea, mouth sores. Psychological disorders such as depression, stress, and anxiety and anger. Meanwhile, the social impact that occurs is the change in the quality of life of individuals from how well humans interact and play a role in their social environment. This is shown in social relationships within the family environment and the surrounding community, contributions made to others, and so on. The quality of life in this dimension will be disturbed when a person is suffering from an illness, thus pulling him into an "isolated" situation and making the social environment "allowing" the sufferer to be free from his social role.

However, this can create burdens for others, including financial burdens for medical expenses, inability to be enthusiastic for their environment and so on. Body image can influence the efficacy of rehabilitation interventions, especially in shortterm follow-up. These various impacts must be overcome because they cause discomfort to the sufferer. Therefore, non- 
pharmaceutical therapy is needed that can reduce the side effects of chemotherapy. These various impacts must be overcome because they cause discomfort to the sufferer. Therefore, non-pharmaceutical therapy is needed that can reduce the side effects of chemotherapy. These various impacts must be overcome because they cause discomfort to the sufferer. Therefore, nonpharmaceutical therapy is needed that can reduce the side effects of chemotherapy. Most women who come to the clinic usually have advanced breast cancer, so it requires a long treatment and costs a lot of money for treatment. Actually, prevention activities are very important as an effort to carry out early detection, so that it can be treated from the start. One way that can be done is to do breast self-examination. The factor associated with breast selfexamination behavior is attitude. Information accessibility, and health service provider support [8]. Aggressive screening and public education programs are needed to prevent cases of increasing breast cancer.

\section{Methods}

This research uses literature study method or literature review. Literature review is a comprehensive summary of research that has been done on a specific topic to show readers what is already known about the topic and what is not known, to find rationale for research that has been done or for further research ideas. Literature studies can be obtained from various sources including journals, books, documentation, internet and literature. The literature study method is a series of activities related to the methods of collecting library data, reading and taking notes, and managing writing materials [9]. The type of writing used is a literature review study that focuses on the results of writing related to the topic or variable of writing. The data used in this research comes from the results of research that have been conducted and published in national and international online journals. In conducting this research, the researchers conducted a search for research journals published on the internet using the Google Scholar and Pubmed search engines with keywords: Breast Cancer, Physiology Impact, Psychology Impact, Social Impact. The data collection process was carried out by filtering based on the criteria determined by the author of each journal taken. The criteria for journal collection are as follows: Year of literature sources taken from 2013 to 2018, suitability of writing keywords, linkages of writing results and discussion. Strategies in collecting journals for various literatures using accredited journal sites such as Google Scholar and Pubmed. 3. An effective way of writing for journal settings by entering keywords according to the title of writing and performing searches based on advance search by adding the AND/OR notation or adding a + symbol. 4 . Search based on full text 5 . Conducting an assessment of the journal from the abstract whether it is based on research objectives and perform critical appraisal with existing tools Systematically the steps in writing literature reviews are as shown Figure 1. 


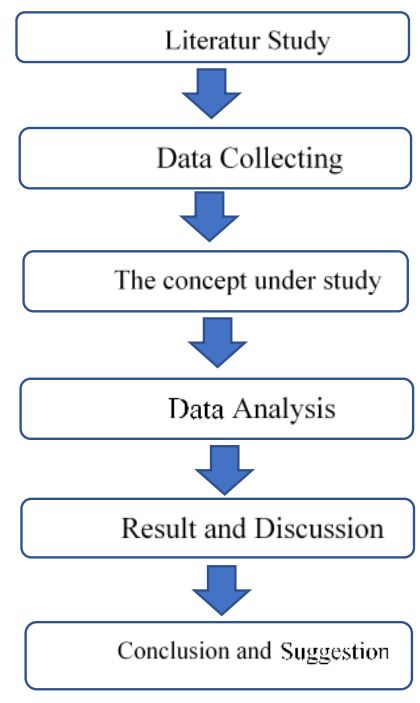

Fig. 1. Flow of literature review

Literature review begins with the written material which is considered sequentially from the most relevant, relevant, and sufficiently relevant. Then read the abstract, each journal first to provide an assessment of whether the problems discussed are in accordance with those to be solved in a journal. Noting the important points and their relevance to the research problem. To keep from getting caught in the plagiarism element, the author should also note the sources of information and include a bibliography. If indeed the information comes from other people's ideas or writing. Make notes, quotes, or information that are arranged systematically so that writing can easily be searched back if at any time needed [2]. Each journal that has been selected based on criteria, a conclusion is made that describes the explanation of self-directed learning in nursing education. Before the author makes conclusions from several literature results, the author will identify in a brief summary form a table containing the author's name, year of writing, study design, samples, instruments (measuring instruments), and research results. After the results of writing from several literatures have been collected, then the authors conduct an analysis of journals that contain the impact of breast cancer from a physiological, psychological and social perspective. Inclusion criteria show in Table 1.

Table 1. Inclusion criteria

\begin{tabular}{ll}
\hline & Inclusion Criteria \\
\hline Periode & Year of Publication \\
Language & English and Indonesia \\
Subject & Breast Cancer Sufferer \\
Types of articles & Original Article \\
Topic of the article & The impacts of breast cancer \\
\hline
\end{tabular}

Research journals that match the inclusion criteria are then collected and a journal summary is made including the name of the researcher, the year of publication of the journal, study design, 
research objectives, samples, instruments and a summary of the findings. The summary of the research journal is entered into a table sorted according to the alfabel and year of publication of the journal and according to the format mentioned above. To further clarify the abstract analysis and full text of the journal, read and observe it. The journal summary is then analyzed for the content contained in the research objectives and the results/research findings. The analytical method used is using journal content analysis.

\section{Results and Discussion}

\subsection{Result}

The results of the literature review stated that 20 journals show the biological/physical impact felt by sufferer cancer is pain, nausea, vomiting, weight loss, hair loss, skin discoloration, and decreased appetite. The psychological impact that is felt is fear of death, anxiety, shame, depression, even to the level of suicidal thoughts. A person with breast cancer will experience changes in his way of life. The uncertainty about remaining life and the existing risk of death makes a person feel that his life is limited. It is normal for cancer sufferers to have a depressive attitude, but some still look fresh and healthy because they try to cover up their illness from those around them and behave like other healthy people, while working on a treatment program to achieve a cure, continue to do activities or work She has been practicing all this time and still has a positive relationship with the people around her. People like this usually have a positive quality of life [10]. The socio-cultural factors form elements of religion (religion), communication, information, social and family support, socio-economic conditions and health services. Socio-cultural factors can affect and improve the quality of life and care for breast cancer patients [11]. Approaches to both spirituality and religiosity do not necessarily show consistent results in affecting quality of life and life satisfaction in cancer patients. Therefore, based on the background of this study, the researcher intends to test whether there is a relationship between spiritual well-being and life satisfaction in breast cancer patients [12].

The results showed that breast cancer clients who undergo chemotherapy are closer to God, namely praying, accepting sincerely, continuing to socialize with other people, and having the hope of getting better in order to be able to carry out spiritual activities to the fullest. Further research is needed which is focused on study of the fulfillment of the spiritual needs of breast cancer clients undergoing chemotherapy [13].

Religious coping has an important role for respondents in dealing with breast cancer or in everyday life [14]. In providing nursing care to cancer clients who are undergoing chemotherapy, the patient's physical and psychological condition must be considered [15]. Negative feelings felt by breast cancer sufferers include anxiety, sadness and fear [16]. Mindfulness based spiritual can improve the spiritual well being of breast cancer patients undergoing chemotherapy [17]. Support for cancer sufferers is very beneficial to improve the quality of life [18]. If the sufferer cannot control his emotions, it will cause negative emotions such as anger, worry, fear, and depression [19]. The highest proportion of late treatment for respondents who lacked social support, there was a relationship between social support and treatment of breast cancer cases [20]. 


\subsection{Discussion}

The psychological condition of breast cancer patients that most respondents felt was helplessness in the form of emotional disturbances such as crying (68\%) and experiencing anxiety in the form of worry thinking about the impact of treatment (84\%). Respondents do not feel ashamed even though they suffer from breast cancer (72\%), do not experience a decrease in self-esteem in the form of pessimism in life (80\%), do not experience stress even though they suffer from breast cancer (64\%), do not experience an angry response in the form of dislike when administered treatment (64\%). Emotional support in the form of expressions of empathy, care and concern for the family concerned. Support of appreciation, this support is in the form of a positive expression of respect for someone. Informative support, this support is in the form of advice, directions and in the form of suggestions to those concerned. Through good family support, it can make an individual more independent and confident in his own abilities. Through this support can increase motivation in a person. Family support is an aspect that is very important and very necessary in determining the speed of the healing process experienced by the patient concerned. Research shows that there is a significant relationship between family social support and breast cancer treatment [21].

\section{Conclusion}

Breast cancer causes various unpleasant effects for the sufferer. The impacts that arise include physical impacts, psychological impacts, and social impacts. The impacts that occur in breast cancer sufferers are in the form of biological/physical impacts, psychological impacts and social impacts that require intervention to overcome them. Suggestion: it is necessary to do nonpharmaceutical therapy to overcome client complaints so that it can support the patient's current medical therapy.

\section{Acknowledgment}

Thank you to the Universitas Muhammadiyah Magelang (UNIMMA) for providing financial assistance for scientific publications. In addition, thanks are also conveyed to all the teams of the UNIMMA Institute for Research and Community Service, who have facilitated the implementation of this international seminar.

\section{References}

[1] Breast Cancer Facts \& Figures 2017-2018, American Cancer Society, Global Headquarters: American Cancer Society Inc. 250 Williams Street, NW, Atlanta. https://www.cancer.org/content/dam/cancer-org/research/cancer-facts-andstatistics/annual-cancerfacts-and-figures/2017/cancer-facts-and-figures-2017.pdf

[2] Breast Cancer/Indonesian. Kanker Payudara. Hospital Authority. All rights reserved. http://kanker.kemkes.go.id/guidelines/PPKPayudara.pdf

[3] Neila Sulung, Rizki Yananda, Adriani. 2018. Determinants of Ca Mammae Incidence in Outpatient Surgery Clinic RSUD Dr. Achmad Mochtar. Jurnal Endurance, 3(3) Oktober 2018 
https://www.researchgate.net/publication/328514970_Determinan_Kejadian_Ca_Mammae_Di_Pol i_Rawat_Jalan_Bedah_Rsud_Dr_Achmad_Mochtar

[4] Makassari Dewi. 2017. The spread of cancer in Indonesia. Indonesian Journal of Cancer Vol. 11, $\begin{array}{llll}\text { No. } & 1 & \text { January-March } & \end{array}$ http://www.indonesianjournalofcancer.or.id/e7journal/index.php/ijoc/article/download/494/242

[5] Evamona Sinuraya. 2016. Quality of Life of Breast Cancer Patients in Oncology 9 Poly RSU Dr. Pirngadi Medan. Jurnal Riset Hesti Medan, Vol. 1, No. 1 Juni 2016

[6] Fitri Haryati, Dian Nur Adkhana Sari. 2019. Relationship of body image with 11 quality of life in breast cancer patients undergoing chemotherapy. Health Sciences and Pharmacy Journal, Vol. 3, No. 2, Agustus 2019, pp. 54-59 http://journal.stikessuryaglobal.ac.id/index.php/hspj

[7] Ministry of Health of the Republic of Indonesia. Breast Cancer Management 16 Guide

[8] Yulianti, I., Setyawan, H., Sutiningsih, D,. 2016. Breast Cancer Risk Factors (Hospital Case Studiesmin Ken Saras Semarang). Jurnal Kesehatan Masyarakat (e19 Journal Volume 4, Nomor 4, Oktober 2016 (ISSN: 2356-3346). https://ejournal3.undip.ac.id/index.php/jkm/article/view/14162

[9] Alvita Brilliana R. Arafah, Hari Basuki Notobroto. 2017. Factors Related to 22 Housewives Conducting Self-Breast Examination. The Indonesian Journal of Public 23 Health, Vol. 12 No. 2, Desember 2017: 143-153. https://e-journal.unair.ac.id/IJPH/article/view/7589/4486

[10] Nursalam. 2016. Nursing Research Methodology.: Pendekatan Praktis. Ed. 4. Jakarta: Salemba Medika

[11] Sinuraya E. 2016. Quality of Life of Breast Cancer Patients in Oncology Poly RSU Dr. Pirngadi Medan. Jurnal Riset Hesti Medan, Vol. 1, No. 1 Juni 2016. http://jurnal.kesdammedan.ac.id

[12] Witdiawati, Purnama D, Eriyani T. 2017. Socio-Culture in the Life of Breast Cancer Clients: Literature Study. Jurnal Keperawatan BSI, Vol. V No. 2 September 2017 ISSN: 2338-7246, e-ISSN: 2528-2239 148. https://ejournal.bsi.ac.id/ejurnal/index.php/jk/article/view/2636/1801

[13] Harlianty RA, Ediati A. 2016. The Relationship Between Spiritual Wellbeing 35 And Life Satisfaction In Breast Cancer Patients In RSUD Dr. H. Abdul Moeloek Provinsi Lampung. Jurnal Empati, April 2016, Volume 5(2), 261-266. http://journal3.undip.ac.id.

[14] Novitasari R, Fauzi AK, Rahman HF, Khotimah H, Wahid AH. 2019. Spiritual experiences of breast cancer clients undergoing chemotherapy. Journal of Health. Vol. 10. No. 3. 2019. http://ejurnal.stikesprimanusantara.ac.id

[15] Nurmahani, ZD. 2017. The Process of Religious Coping in Women with Breast Cancer. Psikologika Volume 22 Nomor 1 Tahun 2017. https://journal.uii.ac.id/Psikologika/article/view/10663

[16] Agustina L, Budiyarti, Yuliani, Ilmi, Bahrul. 2020. Phenomenology Study: Psychology of Cancer Patients Undergoing Chemotherapy. Jurnal Keperawatan Suaka Insan | Volume 5 Edisi I, Juni 2020. https://journal.stikessuakainsan.ac.id/index.php/jksi/article/view/196

[17] Wulandari N, Bahar H, Ismail CS. 2017. Gambaran Kualitas Hidup Pada Penderita Kanker Payudara Di Rumah Sakit Umum Bahteramas Provinsi Sulawesi Tenggara Tahun 2017. Jimkesmas Jurnal Ilmiah Mahasiswa Kesehatan Masyarakat Vol. 2. No. 6/Mei 2017; ISSN 2502-731X. http://journal2.uad.ac.id/index.php/cp/article/view/1771

[18] Wahyuningsih FE, Sofro MAU, Dwidiyanti M. 2019. Spiritual Well being of Breast Cancer Patients Undergoing Chemotherapy through Mindfulness Based Spiritual. Media Keperawatan Indonesia, Vol 2 No 3, Oktober 2019/ page 83-89. http://mki.unimus.ac.id

[19] Yusniarita, Patroni R, Ningsih R. 2016. The Relationship between Spiritual Support and Quality of Life for Breast Cancer Patients after Chemotherapy. Jurnal Media Kesehatan. Vol. 9 No. 2. 2016. http://jurnal.poltekkes-kemenkesbengkulu.ac.id

[20] Kabir ZH, Ariyani Y. 2016. Personal Distress in Husbands with Breast Cancer. Jurnal Penelitian Psikologi 2016, Vol.07, No. 01,36-53. http://jurnalfpk.uinsby.ac.id/index.php/JPP/article/view/95

[21] Aruan, K P., Isfandiari MA. 2015. Relationship between Social Support for Breast Cancer Treatment in Yayasan Kanker Wisnuwardhana. Jurnal Promkes, Vol. 3, No. 2 Desember 2015: https://www.academia.edu/39268328/hubungan_dukungan_sosial_terhadap_pengobatan_kanker_p ayudara_di_yayasan_kanker_wisnuwardhana 